A

Ł

STUDIA Z PRAWA WYZNANIOWEGO

Tom $24-2021$

DOI: https://doi.org/10.31743/spw.12658

\title{
KONKORDAT Z 1925 ROKU W AKTUALNYM ORZECZNICTWIE SĄDOWYM - WYBRANE ZAGADNIENIA
}

Concordat of 1925 in current case law: Selected issues

Streszczenie: W niniejszym artykule omówiono najnowsze i najważniejsze orzeczenia dotyczące postanowień Konkordatu z 1925 r. W relacjach między Państwem polskim a Kościołem Katolickim w okresie II Rzeczypospolitej umowa ta miała bardzo istotne znaczenie, ponieważ uregulowała ona jednolicie sytuację Kościoła na całym obszarze kraju. Pomimo upływu prawie stulecia od podpisania Konkordatu z 1925 r., w ostatnich latach pojawiły się interesujące i nowatorskie orzeczenia, które dotyczą jego postanowień. Sprawy, w których konieczne jest odwołanie się do tej umowy, nie są zbyt częste. Jednak w niektórych zakresach, a zwłaszcza w odniesieniu do kwestii związanych z majątkiem Kościoła Katolickiego, jej postanowienia wciąż posiadają istotne znaczenie. Prezentacja aktualnej ich wykładni przyjmowanej w orzecznictwie Sądu Najwyższego i sądów powszechnych nie tylko umożliwia przewidzenie sposobu rozstrzygnięcia spornych kwestii prawnych w przyszłości, ale też stanowi przyczynek do dyskusji nad niektórymi utrzymującymi się wątpliwościami o charakterze teoretycznym.

Slowa kluczowe: Konkordat z 1925 r.; Kościół Katolicki; II Rzeczpospolita Polska; kościelne osoby prawne; parafia; majątek kościelny; Sąd Najwyższy; źródła prawa

Abstract: This article presents the latest and most important judgments concerning the provisions of the 1925 Concordat. The Concordat of 1925 was of great importance in the relations between the State and the Catholic Church at the time of the Second Polish Republic, because it regulated uniformly the situation of the

* Mgr, Radca Prokuratorii Generalnej RP, Urząd Prokuratorii Generalnej RP, ul. Hoża 76/78, 00-682 Warszawa, e-mail: paulina.kucybala@gmail.com. ORCID: 0000-00022463-9728. 
Church on the territory of the whole country. Despite the fact that the Concordat of 1925 was signed almost a century ago, some interesting and innovative judgments regarding its provisions have been issued in recent years. Although cases which require reference to this agreement are not very frequent, it should be noted that with regard to some issues, especially those pertaining to the property of the Catholic Church, its provisions are still relevant. Therefore, presenting their current interpretation adopted by the Supreme Court and common courts not only makes it possible to predict ways of resolving legal disputes in future adjudications, but it also helps to address some pertinent theoretical questions.

Key words: Concordat of 1925; Catholic Church; Second Polish Republic; church legal entities; parish; church property; Supreme Court; sources of law

\section{WPROWADZENIE}

Celem niniejszego artykułu jest przedstawienie wybranych, aktualnych wypowiedzi sądów powszechnych i Sądu Najwyższego dotyczących regulacji zawartych w Konkordacie z 1925 r. ${ }^{1}$ Wprawdzie sprawy sądowe, w których znaczenie posiadają zagadnienia prawne powstałe na gruncie postanowień Konkordatu z 1925 r. nie są zbyt częste, jednak mimo upływu prawie stulecia od podpisania tej umowy regulacje konkordatowe są wciąż przedmiotem analizy judykatury. Szczególnie w ostatnich latach kwestie związane z Konkordatem z 1925 r. stanowiły przedmiot żywego zainteresowania orzecznictwa. Było to następstwem likwidacji Komisji Majątkowej i przekazaniem do kognicji sądowej (sądów powszechnych rozpoznających sprawy cywilne) roszczeń kościelnych osób prawnych opartych

Problematyka stosunków majątkowych między państwem a Kościołem Katolickim, niezależnie od gwarancji zawartych w Konstytucji marcowej (Dz. U. z 1921 r. Nr 44, poz. 267, dalej: Konstytucja marcowa), była w okresie II RP przedmiotem pertraktacji zakończonych ostatecznie zawarciem pomiędzy Stolicą Apostolską a Rzecząpospolitą Polską Konkordatu podpisanego w Rzymie dnia 10 lutego 1925 r. (Dz. U. z 1925 r. Nr 72, poz. 501), zatwierdzonego na mocy ustawy z dnia 23 kwietnia 1925 r. o zatwierdzeniu układu ze Stolicą Apostolską, określającego stosunek Państwa do Kościoła Rzymskokatolickiego (Dz.U. z 1925 r. Nr 47, poz. 324). Konkordat uzyskał moc prawną z dniem 2 sierpnia 1925 r. i uregulował jednolicie sytuację Kościoła na całym obszarze II RP. Umowa ta składała się z 27 artykułów, które zostały sformułowane w języku francuskim i polskim. 
na art. 61-63 ustawy z dnia 17 maja 1989 r. o stosunku Państwa do Kościoła Katolickiego w Rzeczypospolitej Polskiej ${ }^{2}$ w związku z art. 4 ust. 1 ustawy z 16 grudnia 2010 r. o zmianie ustawy o stosunku Państwa do Kościoła Katolickiego w Rzeczypospolitej Polskiej ${ }^{3}$. Rozstrzygnięcie powyższych spraw w postępowaniach cywilnych było skomplikowane, bowiem wymagało od sądów nie tylko dokonania interpretacji historycznych źródeł prawa, w tym postanowień Konkordatu z 1925 r., ale także retrospektywnej analizy przedwojennego i powojennego orzecznictwa.

W niniejszym artykule uwaga zostanie zwrócona na najistotniejsze zagadnienia, które okazały się relewantne dla roszczeń zgłaszanych przez kościelne osoby prawne w postępowaniach cywilnych. Omówiona zostanie w szczególności problematyka ustawodawstwa pozaborczego, osobowości prawnej jednostek kościelnych, następstwa prawnego, uwłaszczenia osób prawnych Kościoła Katolickiego, regulacji stanu prawnego nieruchomości kościelnych oraz utraty mocy obowiązującej Konkordatu z 1925 r.

\section{KONKORDAT Z 1925 R. W SYSTEMIE ŹRÓDEŁ PRAWA}

W przedwojennej judykaturze uznawano postanowienia Konkordatu z 1925 r. za część polskiego porządku prawnego nie tylko jako umowy międzynarodowej. Postrzegano go również w kategoriach ustawowych. Pogląd taki zaprezentował m.in. Sąd Najwyższy w uzasadnieniu orzeczenia z dnia 23 października - 7 listopada 1929 r., w którym wywiódł: „Konkordat ze Stolicą Apostolską, ratyfikowany przez władzę ustawodawczą zgodnie z przepisami Konstytucji (art. 49) i ogłoszony w dzienniku ustaw (za 1925 r. poz. 324 i 501), jest nie tylko układem międzynarodowym, lecz ustawą, mającą moc obowiązującą w stosunkach wewnętrznych [...]"4. Powyższe stanowisko było aprobowane także w powojennym orzecz-

2 Ustawa z dnia 17 maja 1989 r. o stosunku Państwa do Kościoła Katolickiego w Rzeczypospolitej Polskiej, tekst jedn. Dz. U. z 2019 r., poz. 1347.

3 Ustawa z dnia 16 grudnia 2010 r. o zmianie ustawy o stosunku Państwa do Kościoła Katolickiego w Rzeczypospolitej Polskiej, Dz. U. z 2011 r. Nr 18, poz. 89.

4 Orzeczenie Sądu Najwyższego z dnia 23 października - 7 listopada 1929 r., I C 2343/28, OSP 1930, t. IX, poz. 451, s. 433 i n. Zob. też orzeczenie Sądu Najwyższego z dnia 3 listopada 1932 r., III Rw 1769/32, LEX nr 1670563. 
nictwie, co wynika $\mathrm{z}$ argumentacji sądów sformułowanej w kontekście problematyki utraty mocy obowiązującej Konkordatu z 1925 r. W orzeczeniu z dnia 18 sierpnia 1946 r. (I CZ 83/46) Sąd Apelacyjny w Poznaniu stwierdził, że należy oddzielić skutki obowiązywania Konkordatu z 1925 r. na płaszczyźnie międzynarodowej (ratyfikacja) od skutku obowiązywania umowy w porządku krajowym (publikacja w Dzienniku Ustaw). Konkludując Sąd Apelacyjny w Poznaniu uznał, że chociaż Konkordat z 1925 r., na skutek uchwały Rady Ministrów z dnia 12 września 1945 r. ${ }^{6}$ przestał wiązać Polskę ze Stolicą Apostolską jako traktat międzynarodowy, to jednak stanowił w dalszym ciągu źródło prawa krajowego, gdyż ustawa z dnia 23 kwietnia 1925 r. o zatwierdzeniu układu ze Stolicą Apostolską, określającego stosunek państwa do Kościoła Rzymskokatolickiego, nie została uchylona, a uchwała Rady Ministrów z dnia 12 września 1945 r. nie została opublikowana w zbiorze urzędowym ${ }^{7}$.

Przedstawiona wyżej koncepcja znajduje potwierdzenie również w najnowszym orzecznictwie. Tytułem przykładu można wskazać na wyroki Sądu Najwyższego z dnia 25 lutego 2015 r. ${ }^{8}$ oraz z dnia 9 lutego 2018 r. ${ }^{9}$ W uzasadnieniu pierwszego z powołanych judykatów Sąd Najwyższy wprost odwołał się do powołanego wyżej orzeczenia Sądu Apelacyjnego w Poznaniu z dnia 18 sierpnia 1946 r. i wskazał: „Wyrażony przez Sąd Apelacyjny pogląd znajduje także poparcie we współczesnej literaturze”. Z kolei w wyroku z dnia 9 lutego 2018 r. Sąd Najwyższy wyjaśnił, że „ówczesna doktryna polska stała na stanowisku, że umowy międzynarodowe obowiązują w systemie prawa polskiego ze względu na ich przekształcenie w akty prawa krajowego. Transformacja aktu międzynarodowego w «ustawę» następowała poprzez ratyfikację (która na płaszczyźnie wewnętrznej przekształcała normę międzynarodową w normę

5 Tekst w: ,Tygodnik Powszechny” 1947, nr 43, s. 8.

6 Tekst uchwały w: M. Fąka, Państwowe prawo wyznaniowe Polskiej Rzeczypospolitej Ludowej. Wybór tekstów źródtowych, Warszawa 1978, s. 26-27.

7 Zob. Skubiszewski 1980, 46.

8 Wyrok Sądu Najwyższego z dnia 25 lutego 2015 r., IV CSK 312/14, LEX nr 1663415. Tak też Sąd Apelacyjny w Lublinie w wyroku z dnia 11 lutego 2021 r., I ACa 714/19, niepubl., oraz Sąd Okręgowy w Lublinie w wyroku z dnia 31 maja 2019 r., I C 642/11, niepubl.

9 Wyrok Sądu Najwyższego z dnia 9 lutego 2018 r., I CSK 179/17, LEX nr 2484707. 
krajową o tożsamej treści) i dalej promulgowanie umowy międzynarodowej w Dzienniku Ustaw (co z kolei wywoływało skutek umowy międzynarodowej w stosunkach wewnętrznych - niejako wejście w życie umowy międzynarodowej na potrzeby jego stosowania przez sądy i organy krajowe)". Ogólnie można stwierdzić, że Sąd Najwyższy konsekwentnie stoi na stanowisku, iż Konkordat z 1925 r. wszedł w skład polskiego porządku prawnego jako umowa międzynarodowa i jako ustawa i w ten sposób był też postrzegany przez późniejsze orzecznictwo. Zagadnienie to było rozważane nie tylko w orzecznictwie, ale i w literaturze i można stwierdzić, że w tym zakresie wytworzyła się communis opinio.

\section{PROBLEMATYKA OSOBOWOŚCI PRAWNEJ JEDNOSTEK ORGANIZACYJNYCH KOŚCIOŁA KATOLICKIEGO}

Podmiotowość prawna jest cechą normatywną, nadawaną przez ustawodawcę określonemu tworowi społecznemu. Oznacza to, że określone organizacje są podmiotami prawa wyłącznie $\mathrm{z}$ woli ustawodawcy ${ }^{10}$. Za osobę prawną można uznać jednostkę organizacyjną, która została wyposażona przez normę prawną w zdolność prawną i w związku z tym może być podmiotem stosunków cywilnoprawnych ${ }^{11}$. Z kolei osobowość prawna stanowi atrybut osoby prawnej, dzięki któremu może ona uczestniczyć w obrocie prawnym ${ }^{12}$.

W piśmiennictwie wskazuje się, że problematyka osobowości prawnej Kościoła Katolickiego i jego jednostek organizacyjnych zarówno w świetle prawa kanonicznego, jak i prawa państwowego, należy do zagadnień skomplikowanych ${ }^{13}$. Osobowość cywilnoprawna została zagwarantowana określonym urzędom i instytucjom kościelnym na mocy art. XVI Konkordatu z 1925 r. Zastosowano przy tym kryterium formalne ustalania kościelnych osób prawnych, polegające na przyznaniu osobowości prawnej wszystkim osobom „moralnym” (prawnym) kościelnym i zakonnym posiadającym

10 Wolter, Ignatowicz, Stefaniuk 1998, 204.

11 Tamże, 204.

12 Krukowski 2007, 38.

13 Szerzej zob. Wisłocki 1981, 28; Krukowski 2007, 35. 
taką osobowość według Kodeksu Prawa Kanonicznego z 1917 r. ${ }^{14}$ Przedmiotem analizy orzecznictwa było w związku z powyższym po pierwsze zagadnienie ustalenia kręgu struktur organizacyjnych działających w Kościele Katolickim, które należało uznawać za podmioty prawa na skutek wejścia w życie Konkordatu z 1925 r.

W dawnym orzecznictwie nie budziła wątpliwości sama kwestia odwołania się w art. XVI Konkordatu z 1925 r. do regulacji Kodeksu Prawa Kanonicznego z 1917 r. Taki pogląd wyraził najdobitniej Sąd Najwyższy w orzeczeniu z dnia 24 stycznia 1936 r., w którego uzasadnieniu wskazano: „Od chwili wejścia w moc obowiązującą przepisów Konkordatu decydują wyłącznie przepisy prawa kanonicznego o tym, którym instytucjom kościelnym lub zakonnym, przysługuje osobowość prawna [...]"15. Stanowisko powyższe nie uległo zmianie na gruncie aktualnej judykatury. Kwestię relacji art. XVI Konkordatu z 1925 r. do Kodeksu Prawa Kanonicznego z 1917 r. omówił szczegółowo Sąd Najwyższy w uzasadnieniu wyroku z dnia 25 lutego 2015 r. Jak wyjaśniono, „[z] art. XVI konkordatu wprost wynikało, że wszystkie polskie osoby prawne kościelne i zakonne, mają zgodnie z przepisami prawa powszechnie obowiązującego, prawo nabywania, odstępowania, posiadania i administrowania, według prawa kanonicznego swego majątku ruchomego i nieruchomego, jak również prawo stawania przed wszelkimi instancjami i władzami państwowymi dla obrony swych spraw cywilnych. [...] Skutkiem więc tego postanowienia było uznanie przez prawo polskie osobowości prawnej polskich osób prawnych kościelnych i zakonnych, które miały zdolność prawną i zdolność sądową według Codex Iuris Canonici obowiązującego od dnia 19 maja 1918 r.”'16 Analogiczne stanowisko Sąd Najwyższy zajął

14 Codex Iuris Canonici Pii X Pontificis Maximi iussu digestus Benedicti Papae XV auctoritate promulgatus (27.05.1917), AAS 9 (1917), cz. II, s. 1-593. Szerzej: Wisłocki 1977, 148-152. W piśmiennictwie wskazuje się ponadto, że zarówno pojęcie osoby prawnej, jak i definicja zakresu uprawnień tejże osoby, z uwagi na brak należytej precyzji, powodowały zasadnicze rozbieżności w praktyce obrotu cywilnego; tak m.in. Walencik 2009, 32; Walencik 2013, 15.

15 Orzeczenie Sądu Najwyższego z dnia 24 stycznia 1936 r., C II 2101/35, OSP 1937, poz. 739 .

16 Wyrok Sądu Najwyższego z dnia 25 lutego 2015 r., IV CSK 312/14, LEX nr 1663415. 
W uzasadnieniu wyroku z dnia 2 grudnia 2015 r. ${ }^{17}$ Zostało ono również powszechnie przyjęte w orzecznictwie sądów niższych instancji. Pogląd Sądu Najwyższego powtórzył m.in. Sąd Okręgowy w Poznaniu w wyrokach z dnia 14 marca 2017 r. ${ }^{18}, 23$ maja 2017 r. ${ }^{19}, 2$ czerwca 2017 r. ${ }^{20}, 27$ czerwca 2017 r. ${ }^{21}, 15$ grudnia 2017 r. ${ }^{22}, 5$ października 2018 r. ${ }^{23}$ oraz 6 lutego 2018 r. ${ }^{24}$ Takie samo stanowisko zajął też np. Sąd Apelacyjny w Gdań$\mathrm{sku}^{25}$, a także Sąd Okręgowy w Lublinie ${ }^{26}$. Z kolei w uzasadnieniu wyroku z dnia 6 czerwca 2013 r. Sąd Okręgowy w Toruniu stwierdził: „Kodeks Prawa Kanonicznego z 1917 r. posłużył się figurą prawną «osób moralnych» dla oznaczenia jednostek organizacyjnych Kościoła Katolickiego. Pojęcie to jest odpowiednikiem «osoby prawnej» w prawie świeckim"27.

W judykaturze okresu międzywojennego pojawiła się jednak rozbieżność na gruncie art. XVI Konkordatu z 1925 r., w kontekście instytucji „parafii”. W orzeczeniu z dnia 8 października 1929 r. ${ }^{28}$ Sąd Najwyższy opowiedział się za funkcjonalną (szerszą) wykładnią pojęcia kościelnej osoby prawnej i ostatecznie uznał, że podmiotem majątku, którego dochody są przeznaczone na utrzymanie proboszcza, jest probostwo (parafia) jako

17 Wyrok Sądu Najwyższego z dnia 2 grudnia 2015 r., IV CSK 90/15, LEX nr 2007805.

18 Wyrok Sądu Okręgowego w Poznaniu z dnia 14 marca 2017 r., XVIII C 514/15, LEX nr 2282876.

19 Wyrok Sądu Okręgowego w Poznaniu z dnia 23 maja 2017 r., XVIII C 526/15, LEX nr 2322239.

20 Wyrok Sądu Okręgowego w Poznaniu z dnia 2 czerwca 2017 r., XVIII C 512/15, LEX nr 2356856.

21 Wyrok Sądu Okręgowego w Poznaniu z dnia 27 czerwca 2017 r., XVIII C 525/15, LEX nr 2374963.

22 Wyrok Sądu Okręgowego w Poznaniu z dnia 15 grudnia 2017 r., XVIII C 519/15, LEX nr 2451763.

23 Wyrok Sądu Okręgowego w Poznaniu z dnia 5 października 2018 r., XVIII C 528/15, LEX nr 3041897.

24 Wyrok Sądu Okręgowego w Poznaniu z dnia 6 lutego 2018 r., XVIII C 515/15, LEX nr 2485360.

25 Wyrok Sądu Apelacyjnego w Gdańsku z dnia 4 października 2016 r., V ACa 954/15, V ACz 1003/15, niepubl.

26 Wyrok Sądu Okręgowego w Lublinie z dnia 31 maja 2019 r., I C 642/11, niepubl.

27 Wyrok Sądu Okręgowego w Toruniu z dnia 6 czerwca 2013 r., I C 1389/11, niepubl.

28 Orzeczenie Sądu Najwyższego z dnia 8 października 1929 r., Rw 691/29, OSP 1920 , poz. 13 . 
uznana przez prawo kościelne osoba prawna. Odmienne stanowisko zajął w orzeczeniu z dnia 18 sierpnia - 1 września 1936 r. W tym przypadku Sąd Najwyższy przyjął wąską wykładnię i stwierdził, że parafia katolicka nie jest osobą prawną, nie posiada ustawowego przedstawiciela i w związku z tym powództwo przeciwko niej nie może być wytoczone ${ }^{29}$.

Po II wojnie światowej, w związku z uchwałą Tymczasowego Rządu Jedności Narodowej z dnia 12 września 1945 r. w sprawie Konkordatu z 1925 r., praktykę sądową w omawianej materii ukształtowało postanowienie Sądu Najwyższego z dnia 18 kwietnia 1963 r. ${ }^{30}$ Zgodnie z tym judykatem, stosownie do obowiązującego wówczas porządku prawnego, osobowość prawną miały parafie, diecezje i diecezjalne seminaria duchowne Kościoła Rzymskokatolickiego. Chociaż powyższy pogląd spotkał się w doktrynie z krytyką ${ }^{31}$, w judykaturze został zaakceptowany ${ }^{32}$. Zagadnienie osobowości prawnej parafii, w związku z utrzymującymi się kontrowersjami dotyczącymi omawianego postanowienia Sądu Najwyższego, wymagało jednak uaktualnienia w nowych realiach ustrojowych i w późniejszym czasie nadal było analizowane przez sądy.

Rozbieżności co do posiadania osobowości prawnej przez parafie pod rządami Konkordatu z 1925 r. dostrzec można również w aktualnym orzecznictwie sądowym. Przykładowo w cytowanym wyżej uzasadnieniu wyroku z dnia 6 czerwca 2013 r. Sąd Okręgowy w Toruniu stwierdził, że „Konkordat z 1925 r. wprawdzie szanował podmiotowość prawną kościoła w obrocie cywilnoprawnym [por. art. XVI i XXIV], ale

29 Orzeczenie Sądu Najwyższego z dnia 18 sierpnia - 1 września 1936 r., C I 2792/35, OSP 1937, poz. 125. Zob. też orzeczenie Sądu Najwyższego z dnia 13 kwietnia 1926 r., R 252/26, LEX nr 1631564.

30 Postanowienie Sądu Najwyższego z dnia 18 kwietnia 1963 r., 1 CR 223/63, OSNCP 1964, Nr 10, poz. 198.

31 Zob. Dembski 1981, 2-20.

32 Fakt występowania w obrocie prawnym okresu PRL parafii jako osób prawnych i akceptowania tego stanu rzeczy przez orzecznictwo, mimo braku podstawy prawnej przyznającej parafiom osobowość prawną, znajduje odzwierciedlenie w szeregu rozstrzygnięć sądowych. Przykładowo zob. postanowienie Sądu Najwyższego z dnia 16 maja 1964 r., II CR 221/64, LEX nr 205; postanowienie Sądu Najwyższego z dnia 5 lutego 1966 r., II CR 47/66, LEX nr 5936; uchwała Sądu Najwyższego z dnia 24 stycznia 1968 r., III CZP 86/67, LEX nr 675 oraz wyrok Sądu Najwyższego z dnia 28 lipca 1970 r., III CRN 145/70, LEX nr 6764. 
problematykę parafii pozostawił regulacjom kościelnym". Jak wyjaśniono, ,[z] art. XXIV Konkordatu wynikało, że parafie były uznane za osoby prawne w Państwie Polskim i miały zdolność majątkową. Konkordat nie wzruszył sytuacji własnościowej i beneficjów. Pozostały one w posiadaniu i zarządzie proboszczów"33. Odmienny pogląd został zaprezentowany przez Sąd Okręgowy w Toruniu w uzasadnieniu wyroku z dnia 9 lutego 2017 r. ${ }^{34}$, w którym stwierdzono: „W zakresie ustalenia prawa własności przysługującego poszczególnym kościelnym osobom prawnym decydujące znaczenie miały więc przepisy obowiązującego wówczas prawa kanonicznego. Obowiązywał wtedy kodeks prawa kanonicznego z 17 maja 1917 r. Kodeks ten ustalał, że osobowość prawną posiadają: Kościół - jako całość oraz Stolica Apostolska: kolegium kardynałów, prowincje, diecezje, zgromadzenia zakonne, klasztory, seminaria duchowne, kościoły oraz beneficja. Parafie nie posiadały tej osobowości z mocy samego prawa. Mogły ją uzyskać dopiero na podstawie osobnego dekretu ordynariusza. Dobra materialne, służące zabezpieczeniu materialnemu parafii, wraz z wejściem w życie konkordatu z 1925 roku, stały się własnością beneficjów proboszczowskich oraz kościołów parafialnych". W uzasadnieniu wyroku z dnia 30 maja 2017 r. Sąd Okręgowy w Toruniu stwierdził ponadto: „Po zawarciu Konkordatu w 1925 roku przestały obowiązywać wcześniejsze przepisy regulujące byt kościelnych osób prawnych. W ich miejsce pojawiły się przepisy konkordatu"35. Pogląd ten został podzielony przez Sąd Apelacyjny w Gdańsku, który w wyroku z dnia 18 września 2018 r. oddalił apelacje wniesione przez pozwanych ${ }^{36}$.

W omawianej kwestii wypowiedział się również Sąd Najwyższy m.in. w uchwale składu siedmiu sędziów z dnia 12 września 2018 r. $^{37}$ Przyjęto w niej, że po wejściu w życie Konkordatu z 1925 r. kościelnymi

33 Pogląd ten podzielił Sąd Apelacyjny w Gdańsku w wyroku z dnia 29 listopada 2013 r., V ACa 608/13, V ACz 698/13, LEX nr 1439019, oddalając apelację pozwanej Agencji.

34 Wyrok Sądu Okręgowego w Toruniu z dnia 9 lutego 2017 r., I C 1394/11, niepubl.

35 Wyrok Sądu Okręgowego w Toruniu z dnia 30 maja 2017 r., I C 1396/11, niepubl.

36 Wyrok Sądu Apelacyjnego w Gdańsku z dnia 18 września 2018 r., V ACa 613/17, niepubl.

37 Uchwała składu siedmiu sędziów Sądu Najwyższego z dnia 12 września 2018 r., III CZP 14/18, OSNC 2019, Nr 3, poz. 24. 
osobami prawnymi działającymi w granicach parafii były m.in. beneficja proboszczowskie oraz kościoły parafialne, jeżeli wcześniej zostały utworzone na mocy stosownego dekretu. Zaprezentowany pogląd Sądu Najwyższego został powszechnie przyjęty i pozostaje aktualny ${ }^{38}$.

Abstrahując od powyższego, w piśmiennictwie podkreśla się, że na mocy postanowień Konkordatu z 1925 r. kościelne osoby prawne uzyskały znaczną samodzielność w obrocie cywilnoprawnym ${ }^{39}$. Konsekwencją wejścia w życie tej umowy było m.in. uchylenie obowiązkowego zastępstwa prawnego Kościoła Katolickiego, jego osób prawnych oraz innych jednostek organizacyjnych, w tym majątków kościelnych (beneficjów) przez Prokuratorię Generalną, do czego doszło na podstawie § 1 rozporządzenia Rady Ministrów z dnia 16 grudnia 1925 r. ${ }^{40}$

\section{UWŁASZCZENIE KOŚCIELNYCH OSÓB PRAWNYCH}

Przedmiotem wykładni dokonywanej w praktyce orzeczniczej była także regulacja zawarta w art. XXIV Konkordatu z 1925 r. Kontekst stanowiło w tym przypadku uwłaszczenie osób prawnych Kościoła Katolickiego. Powołany przepis konkordatowy posiadał fundamentalne znaczenie dla sytuacji majątkowej Kościoła Katolickiego i składał się z dziewięciu ustępów, z których każdy dotyczył innych zagadnień. Jego trafnej oceny dokonał H. Misztal. Zdaniem tego Autora art. XXIV był najbardziej kontrowersyjny w całym Konkordacie z 1925 r., bowiem państwo, prezentując koncepcję ciągłości państwowości, postanowiło odpowiadać za czyny państw zaborczych $^{41}$. Unormowanie to dotyczyło przede wszystkim ziemi przejętej w posiadanie przez Kościół Katolicki ${ }^{42}$.

38 Stanowisko to Sąd Najwyższy potwierdził m.in. w wyrokach z dnia 8 listopada 2018 r., II CSK 270/17, LEX nr 2577390; z dnia 12 marca 2020 r., II CSK 676/18, LEX nr 2987237 oraz z dnia 12 marca 2020 r., II CSK 677/18, LEX nr 2987220.

39 Por. Walencik 2013, 15.

40 Rozporządzenie Rady Ministrów z dnia 16 grudnia 1925 r. o uchyleniu ciążącego na Prokuratorii Generalnej obowiązku zastępowania majątków kościelnych, Dz. U. z 1925 r. Nr 127, poz. 904.

41 Zob. Misztal 1996, 127.

42 Gołębiowski 1967, 338-339. 
Odwołując się do najnowszego orzecznictwa dotyczącego omawianych kwestii należy zwrócić uwagę na wyrok z dnia 31 maja 2019 r. ${ }^{43}$ Sąd Okręgowy w Lublinie uwzględnił w nim powództwo jednej z parafii oparte na postanowieniach Układu zawartego dnia 20 czerwca 1938 r. między Rzecząpospolitą Polską a Stolicą Apostolską w sprawie ziem, kościołów i kaplic pounickich, których Kościół Katolicki pozbawiony został przez Rosję $e^{44}$. W uzasadnieniu omawianego judykatu zauważono m.in.: „Sprawa ewentualnego przekazania Kościołowi Katolickiemu na własność była przedmiotem długotrwałych rokowań postkonkordatowych między Rzecząpospolitą Polską a Państwem Watykańskim (Stolicą Apostolską). Ostatecznie status tej ziemi został uregulowany w całości postanowieniami Układu między Stolicą Apostolską a Rzecząpospolitą Polską z 1938 roku. Układ podpisany w dniu 20 czerwca 1938 roku, ratyfikowany został jako umowa międzynarodowa - w dniu 16 marca 1939 roku i ogłoszony w Dzienniku Ustaw RP z 1939 roku, Nr 35, poz. 222 i 223. Dniem wejścia w życie ww. umowy był trzydziesty dzień po wręczeniu dokumentów ratyfikacyjnych, tj. 15 kwietnia 1939 roku". Powyższe stanowisko podzielił Sąd Apelacyjny w Lublinie, stwierdzając w uzasadnieniu wyroku z dnia 21 lutego 2021 r., że ,własność dóbr pounickich przeszła od 15 kwietnia 1939 r. (z mocy Układu między Stolicą Apostolską a Rzecząpospolitą Polską podpisanego w dniu 20 czerwca 1938 r.) na rzecz Kościoła Katolickiego w Polsce [...]"45.

\section{REGULACJA STANU PRAWNEGO NIERUCHOMOŚCI W KSIĘGACH WIECZYSTYCH}

Istotne znaczenie, w kontekście regulacji stanu prawnego nieruchomości, posiadało ponadto zawarcie w Konkordacie z 1925 r. postanowień umożliwiających kościelnym osobom prawnym uzyskanie wpisu tytułu własności

43 Wyrok Sądu Okręgowego w Lublinie z dnia 31 maja 2019 r., I C 642/11, niepubl.

44 Układ ten został zawarty w wykonaniu art. XXIV Konkordatu z 1925 r., a do jego ratyfikacji (jako umowy międzynarodowej) doszło w dniu 16 marca 1939 r. (Dz. U. z 1939 r. Nr 35, poz. 222 i 223).

45 Wyrok Sądu Apelacyjnego w Lublinie z dnia 21 lutego 2021 r., I ACa 714/19, niepubl. 
w księgach wieczystych, na wypadek gdyby ich prawa nie były ujawnione. W art. XXIV ust. 2 tej umowy przewidziano uproszczoną procedurę, która polegała na możliwości dokonania wpisu w księdze wieczystej na podstawie prostej deklaracji ordynariusza (np. biskupa diecezjalnego), którą to deklarację poświadczały władze cywilne. Na tej podstawie Sąd Apelacyjny w Gdańsku w wyroku z dnia 29 listopada 2013 r. ${ }^{46}$ wyjaśnił, że zgodnie z Konkordatem z 1925 r. Rzeczpospolita Polska zgodziła się, aby prawa własności, w razie gdy nie były jeszcze wpisane do ksiąg hipotecznych na imię posiadających je osób prawnych (biskupstw, kapituł, kongregacji, zakonów, seminariów, beneficjów proboszczowskich, innych beneficjów etc.) zostały do nich wpisane na podstawie deklaracji właściwego ordynariusza, poświadczonej przez właściwą władzę cywilną.

W tym miejscu warto przypomnieć, że w celu wykonania art. XXIV ust. 2 Konkordatu z 1925 r. Prezydent RP wydał rozporządzenie z dnia 7 lutego $1928 \mathrm{r}^{47}$ Jak wskazuje S. Gołębiowski w oparciu o materiały archiwalne $^{48}$, do 1939 r. z obszaru całej Polski wpłynęły na tej podstawie 1182 wnioski (brak danych dotyczących powierzchni nieruchomości, do których odnosiły się wnioski) ${ }^{49}$.

\section{DEROGACJA USTAWODAWSTWA POZABORCZEGO}

Kontrowersje w praktyce wywołała także regulacja zawarta w art. XXV Konkordatu z 1925 r., która stanowiła klauzulę derogacyjną i miała na celu głównie wyeliminowanie przepisów byłych państw zaborczych. Zauważyć jednak trzeba, że podobnie potraktowane zostały przepisy ustawodawstwa polskiego, które były sprzeczne z Konkordatem z 1925 r. ${ }^{50}$

46 Wyrok Sądu Apelacyjnego w Gdańsku z dnia 29 listopada 2013 r., V ACa 608/13, V ACz 698/13, niepubl.

47 Rozporządzenie Prezydenta Rzeczypospolitej z dnia 7 lutego 1928 r. o wpisywaniu do ksiąg hipotecznych praw własności polskich osób prawnych kościelnych i zakonnych, Dz. U. z 1928 r. Nr 16, poz. 120.

48 Archiwum Akt Nowych, zespół: MWRiOP, sygn. 723.

49 Gołębiowski 1967, 339.

50 Misztal 1996, 130-131. 
W dniu 26 sierpnia 1925 r. Prezes Rady Ministrów wydał okólnik, w którym zawarto instrukcje dotyczące wykonania art. XXV Konkordatu z 1925 r. w odniesieniu do ustaw, rozporządzeń i dekretów, sprzecznych z postanowieniami tej umowy ${ }^{51}$. W okólniku wyliczono akty prawne uchylone przez Konkordat z 1925 r., które obowiązywały na terenach byłych zaborów do dnia jego wejścia w życie (tj. do 2 sierpnia 1925 r.). W większości dotyczyły one zarządu majątkiem kościelnym oraz odnoszących się do tego możliwości kontroli ze strony państwa. Władze państwowe - jak zauważa K. Krasowski - miały świadomość, że okólnik jest aktem prawnym znacznie niższego rzędu niż uchylane akty prawne i że brak było przeszkód do wydania ustawy czy choćby rozporządzenia przez Prezesa Rady Ministrów (któremu art. 2 ustawy zatwierdzającej Konkordat przyznawał prawo do wydawania rozporządzeń wykonawczych do Konkordatu z 1925 r. $)^{52}$. Okólnik zawierał jednak luki. Nie została w nim wymieniona ustawa pruska z dnia 20 czerwca 1875 r. o zarządzie majątku w katolickich gminach kościelnych $^{53}$, stanowiąca podstawę prawną funkcjonujących na obszarze byłego zaboru pruskiego katolickich gmin kościelnych. Powyższą lukę starała się wypełnić judykatura. Według dawnego orzecznictwa Sądu Najwyższego, zapoczątkowanego orzeczeniem z dnia 31 października $1930 \mathrm{r}$. (III. 2 C 231/30), na obszarze byłego zaboru pruskiego po wejściu w życie Konkordatu z 1925 r. katolickie gminy kościelne „stały się dzierżycielami tych części majątku gmin kościelnych, które przypadają im wg przepisów prawa kanonicznego"54. Sąd Najwyższy uznawał zatem, że miejsce katolickich gmin kościelnych zajęły właściwe osoby prawa kanonicznego, które - jak wyjaśniono w cytowanym orzeczeniu - stały się „dzierżycielami”

51 Okólnik Rady Ministrów z dnia 26 sierpnia 1925 r., M.P. z 1925 r. Nr 204, poz. 877.

52 W ocenie K. Krasowskiego powyższe rozwiązanie było korzystne dla rządu, który miał obawy, że konsekwencją zniesienia ustawodawstwa pozaborczego wobec braku odpowiednich polskich aktów prawnych mogło być powstanie luki prawnej, zatem ich uchylenie winno nastąpić dopiero po wydaniu przepisów wykonawczych do Konkordatu z 1925 r., zaś okólnik miał stanowić wyłącznie instrukcję dla administracji wyznaniowej. Na temat motywów wydania okólnika oraz zajętego w tej sprawie stanowiska Komisji Rządowej i Papieskiej pisze Krasowski 1988, 86.

53 Zob. https://www.sbc.org.pl/dlibra/show-content/publication/edition/8016? id=8016 [dostęp: 05.10.2021].

54 „Czasopismo Adwokatów Polskich - Dział Województw Zachodnich” 1931, nr 1-2, s. 13. 
majątku. Zgodnie z ukształtowanym w okresie międzywojennym orzecznictwem, po gminach katolickich doszło do sukcesji z mocy prawa „właściwych, kościelnych osób prawnych" "55. W uzasadnieniu powołanego wyżej orzeczenia z dnia 31 października 1930 r. Sąd Najwyższy wskazał ponadto, że „mając na uwadze właściwy cel konkordatu idący w kierunku zaprowadzenia od razu i w całej pełni zarządu według norm prawa kanonicznego dojść trzeba do wniosku, że z chwilą wejścia jego w życie przestały w ustroju majątku kościelnego istnieć gminy kościelne jako odrębne jednostki a zwłaszcza jako osoby prawne, i że miejsce ich zajęły właściwe osoby prawa kanonicznego, stając się dzierżycielami tych części majątku gmin kościelnych, które przypadają im według przepisów prawa kanonicznego".

Omawiane zagadnienia zachowały swą aktualność i znaczenie w szczególności w kontekście tzw. postępowań sądowych regulacyjnych. Parafie z terenów byłego zaboru pruskiego, inicjując postępowania sądowe i wykazując swą legitymację procesową ${ }^{56}$, niejednokrotnie powoływały się na dawne wpisy w księgach wieczystych (Grundbuchach), w których jako właściciele były ujawnione katolickie gminy kościelne (Katolische Gemeinde $)^{57}$. Powstała zatem w postępowaniach sądowych konieczność ustalenia, czy i jaki podmiot wszedł w prawa i obowiązki katolickich gmin kościelnych. W związku ze znacznym stopniem skomplikowania stanu prawnego, w postępowaniach sądowych niejednokrotnie były wydawane opinie prawne przez biegłych ad hoc z zakresu prawa wyznaniowego i historii Kościoła. Recepcja orzecznictwa z okresu międzywojennego nie była możliwa ze względu na istniejące rozbieżności ${ }^{58}$. Na brak jednolitości w tym zakresie wskazał Sąd Najwyższy, w szczególności w postanowieniu

55 Zob. przykładowo następujące orzeczenia Sądu Najwyższego: z dnia 31 października 1930 r., III 2 C. 231/30; z dnia 20 listopada 1931 r., III 2 C. 229/3, OSP 1932, poz. 249 oraz z dnia 24 stycznia 1936 r., II C 2101/35, Zb. Urz. 1936, nr 8, poz. 328. Zob. także wyrok Najwyższego Trybunału Administracyjnego z dnia 14 maja 1927 r., I. Rej. 3755/25, OSP 1927, poz. 292.

56 Na temat legitymacji procesowej zob. m.in.: Broniewicz 1958, 276; Jędrejek 2019; Kucybała, Jaślikowski 2017, 722-767.

57 Szerzej na temat charakteru katolickich gmin kościelnych pisze Mezglewski 2015, $277-278$.

58 Sąd Okręgowy w Poznaniu w wyroku z dnia 29 maja 2013 r., XII C 1128/11, niepubl., podkreślił, że powodowa parafia winna w toku postępowania wykazać, iż jest następcą prawnym wskazanej w pozwie katolickiej gminy kościelnej pod tytułem ogólnym. 
z dnia 7 grudnia 2017 r. ${ }^{59}$ i następnie w powołanej wyżej uchwale składu siedmiu sędziów z dnia 12 września 2018 r. W uzasadnieniu postanowienia z dnia 7 grudnia 2017 r. Sąd Najwyższy wyeksponował, że judykatura $\mathrm{w}$ zakresie przedstawionego do rozstrzygnięcia problemu prawnego stała się obecnie niejednolita i wskazał na pogląd Sądu Najwyższego wyrażony w uchwale siedmiu sędziów - zasadzie prawnej - z dnia 19 grudnia 1959 r. ${ }^{60}$ Stwierdzono w niej: „Jednostki organizacyjne związków wyznaniowych działających na obszarze Polskiej Rzeczypospolitej Ludowej nie mogą być uważane w stosunku do niemieckich i gdańskich osób prawnych prawa publicznego za odpowiednie osoby prawne w rozumieniu art. 2 ust. 4 dekretu $\mathrm{z}$ dnia 8.III.1946 r. o majątkach opuszczonych i poniemieckich [...]"61.

Szczególne znaczenie w odniesieniu do omawianej problematyki przyznać należy powołanej wyżej uchwale składu siedmiu sędziów Sądu Najwyższego z dnia 12 września 2018 r. Została ona wydana po rozpoznaniu zagadnienia prawnego przedstawionego przez Sąd Najwyższy postanowieniem z dnia 7 grudnia 2017 r. do rozstrzygnięcia składowi powiększonemu tego Sądu. Zgodnie z tą uchwałą „[p]arafiom Kościoła rzymskokatolickiego położonym na terenie zaboru pruskiego, które po pierwszej wojnie światowej znalazły się w granicach Rzeczypospolitej Polskiej, przysługuje uprawnienie do wystąpienia z roszczeniami przewidzianymi w art. 61 w związku z art. 63 ustawy z dnia 17 maja 1989 r. o stosunku Państwa do Kościoła Katolickiego w Rzeczypospolitej Polskiej [...], dotyczącymi nieruchomości będących wcześniej własnością katolickich gmin kościelnych". W uzasadnieniu tego orzeczenia przedstawiono obszerny, bardzo szczegółowy wywód dotyczący regulacji prawnych

59 Postanowienie Sądu Najwyższego z dnia 7 grudnia 2017 r., II CSK 120/17, LEX nr 2439114.

60 Uchwała składu siedmiu sędziów Sądu Najwyższego z dnia 19 grudnia 1959 r., I CO 42/59, OSNCK 1960, Nr 2, poz. 33.

${ }^{61}$ Zauważyć trzeba, że wpisy w księgach wieczystych na rzecz katolickich gmin kościelnych funkcjonowały przez cały okres dwudziestolecia wojennego (jak i później), mimo że nieruchomości znajdowały się w faktycznym władaniu różnych kościelnych osób prawnych w rozumieniu art. XVI Konkordatu z 1925 r. Konsekwencją zaniechania uporządkowania stanu prawnego w tym zakresie była m.in. trudność w wykazaniu legitymacji procesowej w postępowaniach sądowych przez poszczególne kościelne osoby prawne. 
z zakresu prawa wyznaniowego, obowiązujących w II Rzeczypospolitej na ziemiach byłego zaboru pruskiego, a także postanowień Konkordatu z 1925 r. Uchwała spotkała się w piśmiennictwie z aprobatą ${ }^{62}$. Trafnie wskazuje P. Borecki, że ma ona charakter prawotwórczy i porządkujący, bowiem Sąd Najwyższy uznał sukcesję parafii Kościoła Katolickiego po kościelnych osobach prawnych funkcjonujących do 1918 r. na terenie byłego zaboru pruskiego, pomimo braku bezpośredniej podstawy prawnej ${ }^{63}$.

Brak jest możliwości zaprezentowania w niniejszym artykule wszystkich interesujących wypowiedzi, w uzasadnieniach których sądy odnosiły się do zagadnień poruszanych w cytowanej uchwale $\mathrm{z}$ dnia 12 września 2018 r. Poprzestać należy na stwierdzeniu, że przyjęta przez Sąd Najwyższy linia orzecznicza jest kontynuowana ${ }^{64}$.

\section{DATA UTRATY MOCY OBOWIĄZUJĄCEJ KONKORDATU Z 1925 R.}

W judykaturze akcentuje się, że kwestia obowiązywania Konkordatu z 1925 r. po wybuchu II wojny światowej jako umowy międzynarodowej oraz przepisów wewnątrzkrajowych należy do zagadnień skomplikowanych $^{65}$. Sporne nie jest przy tym, że Konkordat z 1925 r. nie obowiązywał w czasie bezpośrednio poprzedzającym wejście w życie Konkordatu z dnia 28 lipca 1993 r. ${ }^{66}$ Jednolitości stanowisk brakuje natomiast w odniesieniu do przyczyny utraty mocy obowiązującej Konkordatu z 1925 r. oraz daty, od której należy go uważać za nieobowiązujący ${ }^{67}$.

62 Tak np. Borecki 2020, 24.

63 Tamże.

64 Zob. przykładowo: wyrok Sądu Najwyższego z dnia 12 marca 2020 r., II CSK 676/18, LEX nr 2987237; wyrok Sądu Najwyższego z dnia 7 lutego 2019 r., II CSK 120/17, LEX nr 2617932; wyrok Sądu Najwyższego z dnia 8 listopada 2018 r., II CSK 270/17, LEX nr 2577390; wyrok Sądu Apelacyjnego w Poznaniu z dnia 24 lipca 2019 r., I ACa 169/19, LEX nr 2772850; wyrok Sądu Apelacyjnego w Poznaniu z dnia 17 maja 2019 r., I ACa 200/19, niepubl.

65 Tak m.in. Sąd Najwyższy w wyroku z dnia 9 lutego 2018 r., I CSK 179/17, LEX nr 2484707.

66 Konkordat między Stolicą Apostolską i Rzecząpospolitą Polską podpisany dnia 28 lipca 1993 r., Dz. U. z 1998 r. Nr 51, poz. 318.

67 Szerzej: Piotrowski 1947, 12. 
H. Misztal trafnie zauważa, że konsekwencje uznania przez państwo Konkordatu z 1925 r. za nieobowiązujący były bardzo poważne. Od tej daty bowiem nastąpiło zaniechanie przestrzegania przez państwo jego postanowień oraz zaprzestanie traktowania Kościoła Katolickiego w sposób wynikający z przepisów Konstytucji marcowej ${ }^{68}$.

W doktrynie jako datę wygaśnięcia Konkordatu z 1925 r. wskazuje się często dzień 12 września 1945 r. ${ }^{69}$ D. Walencik zauważa jednak, że z treści uchwały TRJN z dnia 12 września 1945 r. nie wynika, że 12 września 1945 r. należało traktować jako dzień, od którego Konkordat z 1925 r. przestał w Polsce obowiązywać; dzień ten dość powszechnie jednak przyjęto za dzień jego wygaśnięcia ${ }^{70}$. Z kolei B. Glinkowski wskazuje, że zwolennicy zerwania Konkordatu z 1925 r. forsowali pogląd, że utracił on moc obowiązującą już wcześniej, a mianowicie z dniem 1 grudnia 1939 r., tj. z dniem pierwszego z zarzucanych Stolicy Apostolskiej naruszeń postanowień konkordatowych ${ }^{71}$.

Również stanowisko judykatury nie jest w powyższej kwestii jednolite. W dawnym orzecznictwie natrafić można na poglądy, że Konkordat z 1925 r. obowiązywał nadal, mimo wydania uchwały z dnia 12 września 1945 r. ${ }^{72} \mathrm{~W}$ najnowszych orzeczeniach wyrażono natomiast kilka odmiennych stanowisk co do momentu utraty mocy obowiązującej przez Konkordat z 1925 r. Zasadniczo jednak w tym kontekście wskazuje się na dwie daty: 8 maja 1945 r. lub 12 września 1945 r. W uzasadnieniu wyroku z dnia 25 lutego 2015 r. Sąd Najwyższy stwierdził: „Nie wdając się w spory, mające niejednokrotnie podłoże polityczne, należy podnieść, że konkordat przestał obowiązywać jako umowa międzynarodowa w wyniku uchwały Rady Ministrów Tymczasowego Rządu Jedności Narodowej z dnia 12 września 1945 r." ${ }^{\text {73 }}$ Za datę wygaśnięcia Konkor-

68 Misztal 1996, 181.

69 Zob. Skubiszewski 1981, 35-47; Rybczyński 1980, 49-62; Mezglewski, 1998, 325-341; Piotrowski 1947, 12.

70 Walencik 2009, 42; Świątkowski 1963, 32-33.

71 Glinkowski 2007, 191.

72 Szerzej: Szwarcenberg-Czerny 1948, 15; Walencik 2016, 236; Mezglewski 2015, 282.

73 Wyrok Sądu Najwyższego z dnia 25 lutego 2015 r., IV CSK 312/14, Lex 1663415. Tak też: Sąd Apelacyjny w Lublinie w wyroku z dnia 11 lutego 2021 r., I ACa 714/19, niepubl. oraz Sąd Okręgowy w Lublinie w wyroku z dnia 31 maja 2019 r., I C 642/11, niepubl. 
datu z 1925 r. przyjęto zatem w omawianym orzeczeniu dzień 12 września 1945 r. Odmienny pogląd w tej materii Sąd Najwyższy zaprezentował w wyroku z dnia 15 grudnia 2016 r.; ustalając datę wygaśnięcia Konkordatu z 1925 r. wskazano na dzień 8 maja 1945 r. ${ }^{74}$ Analogiczne stanowisko Sąd Najwyższy zajął w wyroku z dnia 9 lutego 2018 r. ${ }^{75}$, uznając: „Konkordat pomiędzy Stolicą Apostolską a Rzecząpospolitą Polską podpisany w Rzymie w dniu 10 lutego 1925 r. [...] przestał obowiązywać jako umowa międzynarodowa (akt prawa międzynarodowego) oraz ustawa krajowa z dniem zakończenia drugiej wojny światowej, na skutek zasadniczej zmiany okoliczności, na podstawie zwyczajowej klauzuli rebus sic stantibus".

$\mathrm{Na}$ marginesie prowadzonych rozważań warto wskazać, że jeszcze inne stanowisko w 1945 r. prezentowała ówczesna Prokuratoria Generalna, która w piśmie z dnia 10 listopada tego roku wskazała: „Konkordat kościelny obowiązuje nadal, do nowego aktu prawodawczego ustanowionego w Konstytucji”. Przyjęcie interpretacji Prokuratorii Generalnej prowadziłoby do wniosku, że moment wygaśnięcia Konkordatu z 1925 r. nastąpił 22 lipca 1952 r., tj. w chwili uchwalenia Konstytucji PRL ${ }^{76}$. W aktualnym orzecznictwie Sądu Najwyższego i sądów powszechnych próżno jednak szukać aprobaty dla tej opinii.

\section{PODSUMOWANIE}

Na podstawie przeprowadzonych wyżej rozważań należy stwierdzić, że postanowienia Konkordatu z 1925 r. wciąż stanowią przedmiot zainteresowania judykatury. Szczególnie wart podkreślenia jest fakt, że w ostatnich latach ujawniły się niektóre skomplikowane zagadnienia prawne powstałe na gruncie poszczególnych postanowień Konkordatu z 1925 r., a także rozbieżności interpretacyjne, które wymagały rozpoznania przez Sąd Najwyż-

74 Wyrok Sądu Najwyższego z dnia 15 grudnia 2016 r., II CSK 634/15, LEX nr 2224606. W uzasadnieniu tego wyroku stwierdzono m.in.: „Konkordat pomiędzy Stolicą Apostolską a Rzecząpospolitą Polską, podpisany w Rzymie dnia 10 lutego 1925 r. [...], utracił moc obowiązującą z dniem 8 maja 1945 r. na skutek istotnej zmiany okoliczności (clausula rebus sic stantibus)".

75 Wyrok Sądu Najwyższego z dnia 9 lutego 2018 r., I CSK 179/17, LEX nr 2484707.

76 Szerzej: Dembski 1981, 4-6; Szwarcenberg-Czerny 1948, 15. 
szy, a nawet podjęcia przezeń uchwały w powiększonym składzie (powołana wyżej uchwała z dnia 12 września 2018 r.). Omówione w niniejszym artykule wypowiedzi judykatury niewątpliwie zasługują na uwagę, ponieważ mają charakter precedensowy, aktualizując wykładnię postanowień Konkordatu z 1925 r. W dotychczasowym piśmiennictwie nie zostały one jednak przedstawione w sposób wyczerpujący.

Przeanalizowane w niniejszym artykule rozstrzygnięcia sądowe nie wyczerpują problematyki związanej z wykładnią postanowień Konkordatu z 1925 r. przyjmowaną w postępowaniach cywilnych. Skoncentrowano się na najistotniejszych judykatach, w których zaprezentowano poglądy prawne tworzące jednolitą linię orzeczniczą.

Judykatura ma decydujący wpływ na faktyczne kształtowanie się stosunków prawnych. Przedstawienie aktualnej wykładni norm prawnych dokonywanej przez Sąd Najwyższy i sądy powszechne jest zatem bardzo istotne, bowiem znajdzie ona zastosowanie również przy rozstrzyganiu szeregu kwestii prawnych w przyszłości.

\section{BIBLIOGRAFIA}

Borecki, Paweł. 2020. „Prawotwórcza i porządkująca rola Sądu Najwyższego w sprawach wyznaniowych - uwagi w sprawie uchwały składu siedmiu sędziów Sądu Najwyższego z 12.09.2018 r., III CZP 14/18”. Przegląd Sądowy 1: $23-37$.

Broniewicz, Witold. 1963. Legitymacja procesowa. Łódź: maszynopis pracy habilitacyjnej (Biblioteka Uniwersytetu Warszawskiego, sygn. 233812).

Dembski, Krzysztof. 1981. „Osobowość prawna Kościoła Katolickiego w PRL”. Ruch Prawniczy, Ekonomiczny i Socjologiczny 18/3: 1-20.

Fąka, Marian. 1978. Państwowe prawo wyznaniowe Polskiej Rzeczypospolitej Ludowej. Wybór tekstów źródlowych. Warszawa: Akademia Teologii Katolickiej.

Glinkowski, Benedykt. 2007. „Regulacje prawne polskich konkordatów z roku 1925 i 1993 w odniesieniu do mienia nieruchomego Kościoła katolickiego". Poznańskie Studia Teologiczne 21: 177-197.

Gołębiowski, Sławomir. 1967. „Z problematyki reformy rolnej gruntów kościelnych w Polsce w latach 1918-1950". Nowe Prawo 3: 336-346.

Jędrejek, Grzegorz. 2019. Legitymacja procesowa w postępowaniu cywilnym. Warszawa: Wolters Kluwer Polska. 
Jodłowski, Jerzy, Władysław Siedlecki. 1958. Postępowanie cywilne. Część ogólna. Warszawa: Państwowe Wydawnictwo Naukowe.

Klafkowski, Alfons. 1963. „Prawo międzynarodowe a Stolica Apostolska”. Życie i Myśl 11-12: 1-32.

Krasowski, Krzysztof. 1988. Związi wyznaniowe w II Rzeczypospolitej. Studium prawnohistoryczne. Warszawa - Poznań: Państwowe Wydawnictwo Naukowe. Krukowski, Józef. 2007. „Funkcje publiczne a osobowość publicznoprawna kościołów". W: Funkcje publiczne związków wyznaniowych. Materiały III Ogólnopolskiego Sympozjum Prawa Wyznaniowego (Kazimierz Dolny, 16-18 maja 2006), red. Artur Mezglewski, 35-58. Lublin: Wydawnictwo KUL.

Kucybała, Paulina, Marek Jaślikowski. 2017. „Legitymacja ad causam Agencji Nieruchomości Rolnych (Krajowego Ośrodka Wsparcia Rolnictwa) w sprawach związanych z gospodarowaniem nieruchomościami rolnymi Skarbu Państwa". W: Prawo i Państwo. Ksiega jubileuszowa 200-lecia Prokuratorii Generalnej Rzeczypospolitej Polskiej, red. Leszek Bosek, 721-767. Warszawa: Wydawnictwo Sejmowe.

Mezglewski, Artur. 1998. „Spór o wygaśnięcie konkordatu polskiego z 1925 roku”. Roczniki Nauk Prawnych 8: 325-341.

Mezglewski, Artur. 2015. „Opinia prawna dotycząca następstwa prawnego po katolickich gminach kościelnych, istniejących w byłym zaborze pruskim”. Przeglad Prawa Wyznaniowego 7: 277-288.

Misztal, Henryk. 1996. Polskie prawo wyznaniowe. Lublin: Wydawnictwo KUL.

Piotrowski, Stanisław. 1947. „Konkordat zawarty ze Stolicą Apostolską w 1925 r. przestał obowiązywać jako wewnętrza ustawa krajowa”. Państwo i Prawo 12: 3-8.

Rybczyński, Henryk. „W sprawie Konkordatu między Stolicą Apostolską a Rzecząpospolitą Polską z 10 lutego 1925 roku". W: Kościót w Drugiej Rzeczypospolitej, red. Zygmunt Zieliński, Stanisław Wilk, 49-52. Lublin: Towarzystwo Naukowe KUL.

Skubiszewski, Krzysztof. 1981. „Konkordat z 10 lutego 1925 r. Zagadnienia prawnomiędzynarodowe". W: Kościót w Drugiej Rzeczypospolitej, red. Zygmunt Zieliński, Stanisław Wilk, 35-47. Lublin: Towarzystwo Naukowe KUL.

Szwarcenberg-Czerny, Kazimierz. 1948. „Problem polskiego Konkordatu”. Rozprawy „Przegladu Powszechnego” 1: 5-15.

Świątkowski, Henryk. 1962. Wyznaniowe prawo państwowe. Warszawa: Państwowe Wydawnictwo Naukowe.

Walencik, Dariusz. 2009. Rewindykacja nieruchomości Kościoła katolickiego w postępowaniu przed Komisja Majątkowa. Lublin: Wydawnictwo KUL. 
Walencik, Dariusz. 2013. Nieruchomości Kościoła katolickiego w Polsce w latach 1918-2012. Regulacje prawne - nacjonalizacja - rewindykacja. Katowice: Drukarnia Archidiecezjalna.

Wisłocki, Jerzy. 1977. Konkordat Polski z 1925 roku. Zagadnienia prawno-polityczne. Poznań: Wydawnictwo Naukowe UAM.

Wisłocki, Jerzy. 1981. Uposażenie Kościoła i duchowieństwa katolickiego w Polsce 1918-1939. Poznań: Wydawnictwo Naukowe UAM.

Wolter, Aleksander, Jerzy Ignatowicz, Krzysztof Stefaniuk. 1998. Prawo cywilne. Zarys części ogólnej. Warszawa: Wydawnictwo Prawnicze PWN. 
